\title{
Erratum to: Max Charlesworth's Sophia: The First Half-Century and the Next
}

\author{
Jay L. Garfield
}

Published online: 28 March 2013

(C) Springer Science+Business Media Dordrecht 2013

Erratum to: SOPHIA (2012) 51:419-421

DOI 10.1007/s11841-012-0352-y

In Sophia 51.4, p.419, 'Professor Max Charlesworth, OAM' should read 'Professor Max Charlesworth, AO'; and in the corresponding footnote, 'Medal of Order of Australia' should read 'Officer of the Order of Australia'.

Our apology for the error and any misunderstanding it may have caused.

The online version of the original article can be found at http://dx.doi.org/10.1007/s11841-012-0352-y.

J. L. Garfield $(\bowtie)$

Smith College, Northampton, MA, USA

e-mail: jgarfiel@smith.edu

J. L. Garfield

Melbourne University, Melbourne, Australia

J. L. Garfield

University of Tibetan Tibetan Studies, Sarnath, India 